\title{
ALGAL DIVERSITY OF KHADE GANESH JI TEMPLE POND KOTA (RAJASTHAN)
}

\author{
DILIP KUMAR RATHORE*, DIKSHA and RUCHI SAGAR
}

Department of Botany, Government College, Bundi (Rajasthan)

\begin{abstract}
Algae are most common primary producers in the world. These are ubiquitous, photosynthetic, oxygen evolving organism, uni to multicellular, filamentous to colonial, micro to macroalgal forms. Studied pond is situated in the front of temple which adds extra beauty to the temple in Kota district of Rajasthan. Total 18 algal species were identified which belonging to three major classes of the algae $e$.g. Chlorophyceae, Cyanophyceae and Bacillariophyceae. Some of common genera belonging to the class Chlorophyceae are Scenedesmus, Cosmarium, Oedogonium, Spirogyra. Lyngbya and Oscillatoria of Cyanophyceae and some of the common diatoms are Nitzschia, Navicula, Fragillaria. So, the present investigation would form a basis for further studies and provide an indication about water quality and status of aquatic ecosystem. It will also help to prepare a flora of the region.
\end{abstract}

Key words : Freshwater body, Biodiversity, Chlorophyceae, Cyanophyceae, Bacillariophyceae.

\section{INTRODUCTION}

Algae are common and natural inhabitants of surface water and represent an essential and basic part of the aquatic ecosystem and food cycle. Freshwater bodies are extremely complex ecosystems. The physio-chemical and biological properties give each water body its own characteristics. Freshwater bodies are also important sources of primary production. In freshwater ecosystems, loss of indigenous biodiversity is a pervasive environmental issue. Species, genetic diversity and unmodified indigenous communities are all components of biodiversity. The knowledge in the field of algae is growing. The application of algae in medicine, agriculture, fishery, nutrition and the bioactive compound production industries are well established. Issues related to environment, food and energy have offered serious challenge to the stability of nation-states (Tilman et al.,2009). Kota district situated in the southern parts of Rajasthan has encompass total area of $5198.15 \mathrm{sq} / \mathrm{km}$. Khade Ganesh ji temple is a historical temple in Ganeshnagar Kota. The temple is 600 years old. Pond is situated in the front of temple which adds extra beauty to the temple. The present study has been done from unexplored area of Kota region.

Algal diversity has been studied by many workers in India (Desikachary, 1959; Shrivastava,2000 and Srivastava et al.,2018). Singh (1961) investigated the periodicity of cyanobacteria in rice fields in U.P. and Bihar and found three prominent filamentous and heterocystous forms; i.e. Aulosira fertilissima, Anabaena ambigua and Cylindrospermum ghorakhpurease. The seasonal variation of phytoplankton in lakes has been studied by different workers (Kaur et al.,2002 and Jarousha,2002). Recently phytoplankton of freshwater rivers and lakes in India have been studied in detail (Bajpai et al.,2019; Rajyalaxmi \& Aruna,2019; Asulabha et al.,2018; Annalakshmi \& Amsath,2012; Shashi Shekhar et al.,2008; Bhatnagar \& Bhardwaj,2013; Tiwari \& Chauhan,2006; Das \& Adhikary,2012; Anuja \& Chandra,2012 and Rout \& Borah, 2009).
The present investigation would form a basis for further studies and provide an indication about water quality and status of aquatic ecosystem. It will also help to prepare a flora of the region.

\section{MATERIAL AND METHODS}

The major algae were collected by forceps but micro/unicellular algae were collected by phytoplanktonic net. Samples collected were fixed and stored in marked plastic bottles. After collection, phytoplanktons were centrifuged and the supernatant liquid was siphoned off, the sedimented portion and other major algal forms being preserved in 4 per cent formaldehyde. The systematic identification of algae was done with the help of the standard works (Fritsch,1935; Randhawa,1959; Prescott,1962; APHA,2018; Palmer,1980; Bold \& Wynne, 1978 and Desikachary,1959).

\section{RESULTS AND DISCUSSION}

Eighteen algal flora were identified which belonging to the class Chlorophyceae (Green algae), Cynophyceae (Blue green algae) and Bacillariophyceae (Diatoms). The study in this pond show rich diversity of algae belonging to various classes. The Systematic enumerations of identify algae observed from studied pond are follow:

\section{Chlorophyceae :}

Scenedesmus bijugetus (Turpin) Kuetzing (Figs.1\&15).

Colonies flat or slightly curved, without spine, 4 celled arranged in linear, cell oblong to ovoid with rounded ends. Cells are $4.87 \mu$ broad and $14.96 \mu$ long.

\section{Characium ambiguum Hermann ex Rabenhorst (Fig.2).}

Cell small, elongated and oblique, apices slightly bend with hyaline beak, alga attached through with short stalk, without basal thickening. Cells are $7.48 \mu$ broad and $29.92 \mu$ long. 


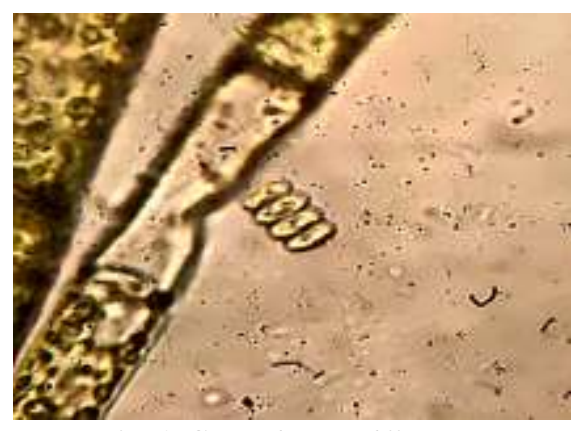

Fig. 1 Scenedesmus bijugetus

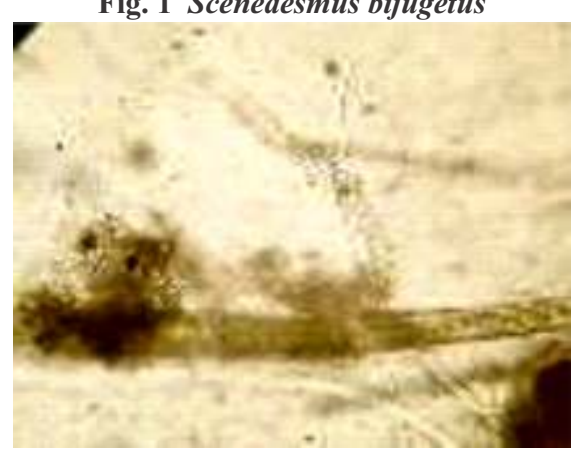

Fig. 4 Spirulina gigantea

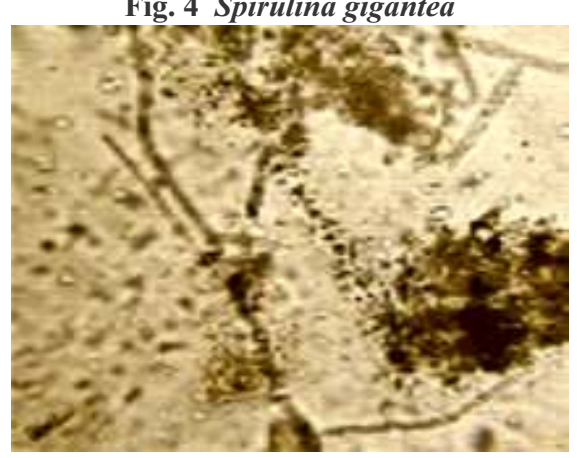

Fig. 7 Lyngbya ahieronymusii

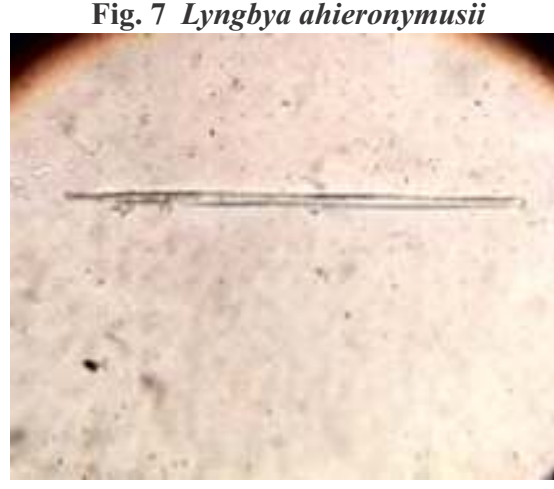

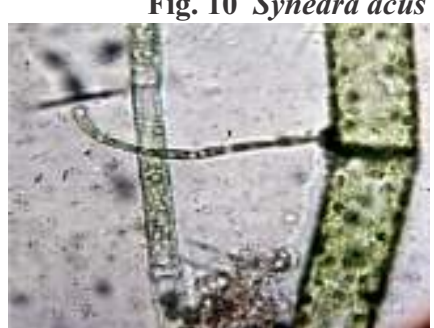

Fig. 13 Ulothrix Sp.

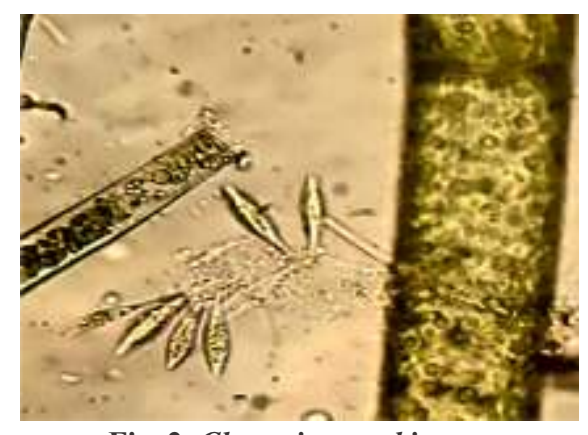

Fig. 2 Characium ambiguum

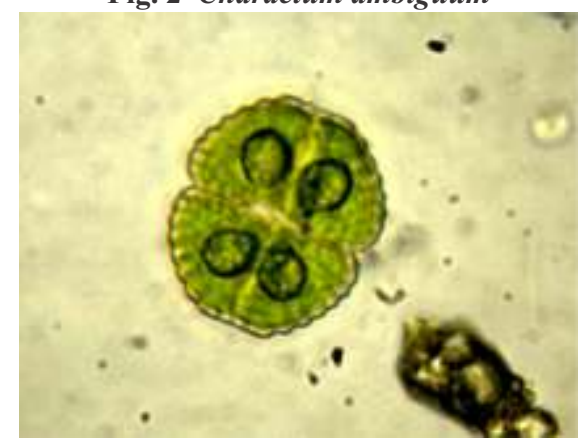

Fig. 5 Cosmarium subcostatum

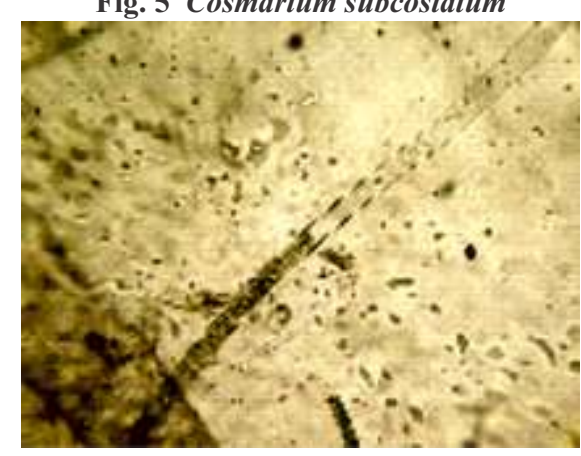

Fig. 8 Oscillatoria obscura

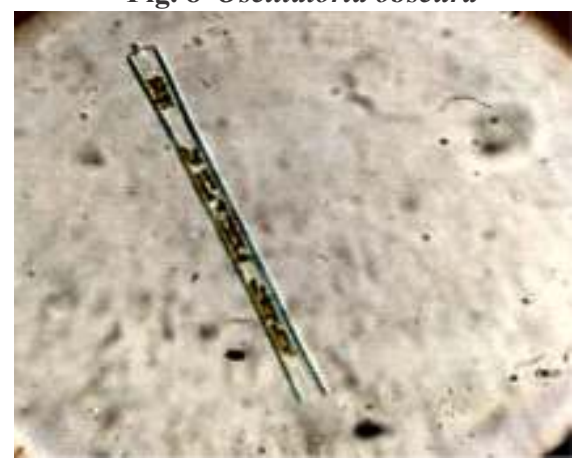

Fig. 11 Fragilaria capucina Desmaz var gracili

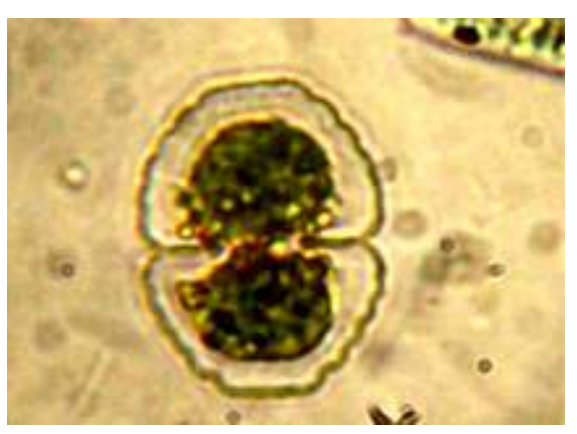

Fig. 3 Cosmarium impressulum

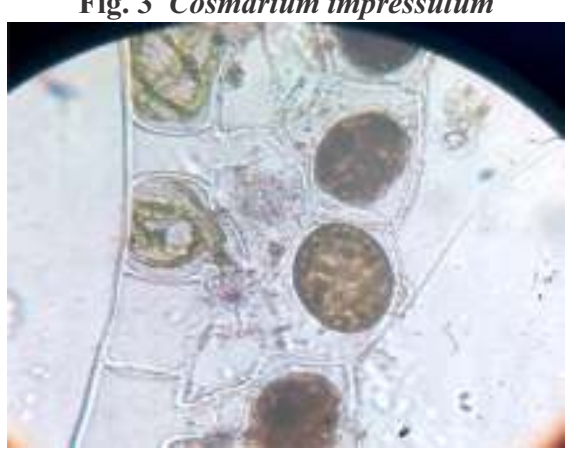

Fig. 6 Spyrogyra hyaline

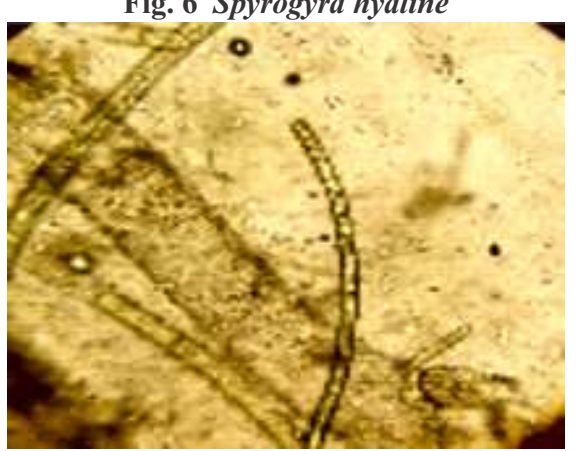

Fig. 9 Oscillatoria proteus

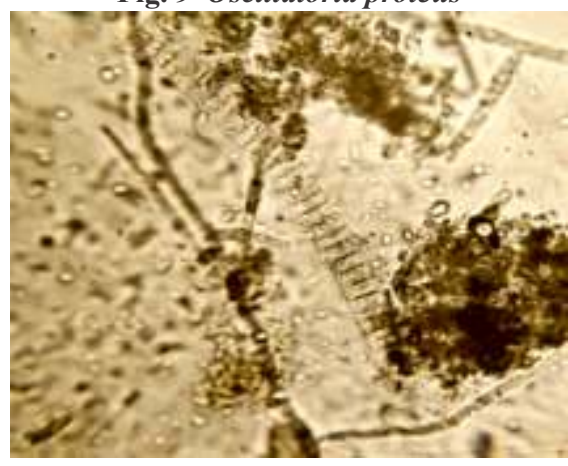

Fig. 12 Fragilaria crotonensis

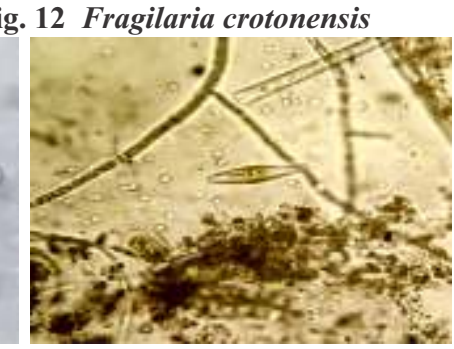

Fig. 16 Navicula Sp.

Figs. 1 to 16 Algal diversity of Khade Ganesh Ji Temple, Kota (Rajasthan). 


\section{Spyrogyra hyaline Clave (Fig.6)}

Two chloroplast, Vegetative Cell $59.84 \mu$ broad, $210.72 \mu$ long, Conjugation lateral or scalariform, tubes formed by both gametangia, fertile cells cylindric or slightly inflated. Zygopspores ellipsoid, more or less pointed, $71.06 \mu$ broad and $97.24 \mu$ long.

\section{Ulothrix Spp. (Fig.13)}

Unbranched simple filament, apical end cell rounded and basal hold fast, cell elongated which attached filament to substratum. Cells are $3.74 \mu$ broad and $24.94 \mu$ long.

\section{Closterium rostatum (Fig.14)}

Unicellular elongated cell, tapering at both ends, crescent shaped, 2 chloroplast contain in single cell, numerous pyrenoids, separated in the middle of the cell by a nucleus.

\section{Cosmarium impressulum Elfving (Fig.3)}

Cell body small, $30.52 \mu$ long, $16.84 \mu$ wide, isthmus $5.3 \mu$ wide, both sides of semicells with four wavy margins, all waves equal in size, side view elongated ellipsoid; cell wall smooth.

\section{Cosmarium subcostatum Nordstedt (Fig.5)}

Cell surface granulated, gnarled, semicells pyramidal with flattened apex. Cell body $33.65 \mu$ long, $25.78 \mu$ wide, isthmus $8.56 \mu$.

\section{Cynophyceae :}

\section{Spirulina gigantea Schmidle (Fig.4)}

Deep blue green, regularly spirally coiled, at the end conical attenuated, free floating. Trichome $14.96 \mu$ broad, spiral away from each other and cell widths is $3.74 \mu$.

\section{Lyngbya ahieronymusii Lemm (Fig.7)}

Unbranched Filament single, with micro vacuole, free floating, straight or slightly bent, end sheath firm, sheath color yellow green, transparent, septa granulated. Trichome with sheath $14.96 \mu$ broad and without sheath 11.22-13.09 $\mu$ long.

\section{Oscillatoria obscura Bruhl et Biswas (Fig.8)}

Trichome not spiral, blue green, cross wall granulated and cell rounded without sheath, attenuated at the apex slightly bent or nearly straight, size of the trichome is $9.35 \mu$ broad and $2.8 \mu$ long.

\section{Oscillatoria proteus Skuja (Fig.9)}

Straight trichome, end rounded, cross wall granulated, harmogonia present in separation, calyptra absent, dull blue green, cell $7.48 \mu$ broad and $3.74 \mu$ long.

\section{Bacillariophyceae :}

Synedra acus Kutz (Fig.10)

Valve slightly capitates, 90.0-110.0 $\mu \mathrm{m}$ long, 4.0-5.0 $\mu \mathrm{m}$ wide. $\mathrm{pH}$ alkaliphilous.

\section{Fragilaria crotonensis Kitton (Fig.12)}

Valve broadly elliptical,valves $90.0 \mu \mathrm{m}$ long and $5.0 \mu \mathrm{m}$ wide. The striae ranging $14-15$ in $10 \mu \mathrm{m}$.

Fragilaria capucina Desmaz var. gracilis (Str.) A. Cleve (Fig.11)

This entity is commonly found in study area. Valve length up to $65.0 \mu \mathrm{m}$ and width up to $5.0 \mu \mathrm{m}$.

\section{Navicula Sp. (Fig.16)}

Valves lanceolate with rostrate apices 18.0-25.0 $\mu \mathrm{m}$ long and 9.0-10.0 $\mu \mathrm{m}$ wide, central area clear orbicular; axial area clear, number of striae in $10 \mu \mathrm{m} \mathrm{11-12,} \mathrm{raphe} \mathrm{straight} \mathrm{some-}$ what bifurcate at apex.

The present work showed that many algal species are occurs in this pond. Some of common genera belonging to the class Chlorophyceae are Scenedesmus, Cosmarium, Oedogonium, Spirogyra. Lyngbya and Oscillatoria of Cyanophyceae and some of the common diatoms are Nitzschia, Navicula, Fragillaria. Thus studies on algae can play an important role in ecological management and in continue an investigation at the population level in the water body. The rich algal flora generally occurs at the places with high level of nutrients and presence of warm and sunny conditions. It promotes the plant growth, favouring certain species over others and forcing a change in species composition. However, human activity can often trigger and accelerate the pace of algal growth.

\section{ACKNOWLEDGMENT}

The authors are thankful to the Head, Dept. of Botany and Principal, Government College Bundi (Rajasthan) for providing laboratory facilities and encouragement.

\section{REFERENCES}

APHA (2018). Standard Methods for the Examination of Water and Waste-water. American Water Works Association and Water Pollution Control Federation, Washington, DC, USA

Annalakshmi, G. and Amsath, A. (2012). Studies on the hydrobiology of river Cauvery and its tributaries Arasalar from Kumbakonam region with reference to phytoplankton. IJPAES, 2(2): 37-46.

Anuja, J. and Chandra, S. (2012). Studies on fresh water algae in relation to chemical constituents of Thiruneermalai temple tank near Chennai. International Journal of Current Science, 4 : 21-29

Asulabha, K. S.; Varghese, S.; Jaishanker, R. and Ramachandra, T. V. (2018). Algal Diversity in Urban Lakes of Vrishabhavathi Valley, Greater Bangalore. Proceeding Paper in Conference on Conservation and Sustainable Management of Riverine Ecosystems. 
Bajpai, O.; Narendra, M.; Jitendra, M. and Gupta, R. K. (2019). An annual algal diversity of Lakhna, Etawah, 11 : 619-623.

Bhatnagar, M. and Bhardwaj, N. (2013). Biodiversity of algal flora in river Chambal at Kota (Rajasthan). Nature Environment and Pollution Technology, 12(3): 547 .

Bold, H. C. and Wynne, M. J. (1978). Introduction to the algae, structure and reproduction. Prentice Hall Inc., NJ.

Das, S. K. and Adhikary, S. P. (2012). Algal diversity in the reservoirs of Odisha state, India. Indian Hydrobiology, 15 : 17-41.

Desikachary, T. V. (1959). Cyanophyta: Vol. 2. Indian Council of Agricultural Research, New Delhi.

Fritsch, F. E. (1935). The Structure and Reproduction of the Algae: Vol. I. Cambridge University Press, London, xvii + 791 p. , 2454.

Jarousha, A. K. K. H. (2002). Analysis of the polluting elements of Ramgarh lake of Jaipur (Rajasthan). In : Algal biotechnology. Pointer Publishers, Jaipur.

Kaur, H.; Jerath, N.; Sajeev, K. and Bath, K. S. (2002). Aquatic plant diversity of Ropar wetland. Indian Journal of Environmental Sciences, 6(1): 23-26.

Palmer, C. M. (1980). Algae and Water Pollution, Castle House Publication Ltd., England.

Prescott, G. W. (1962). Algae of the Western Great Lakes area. Wm. C. Brown Co., Doubuque, lowa.

Rajyalaxmi, K. and Aruna, M. (2019). Distributional status of the diversity of phytoplankton population in fresh water lake. International Journal of Scientific Research in Science, Engineering and Technology, pp. 227-234.

Randhawa, M. S. (1959). Zygnemaceae. Indian Council of Agricultural Research, New Delhi, p. 478.

Rout, J. and Borah, D. (2009). Algal diversity in Chatla wetland in Cachar district (Southern Assam). Assam Uni. J. of Sci and Technology Biol., Sci., 4(1): 46-55.

Shashi Shekhar, I. R.; Kiran, B. R.; Puttaiah, E. T.; Shivraj, Y. and Mahadevan, K. M. (2008). Phytoplankton as index of water quality with reference to industrial pollution. Journal of Environmental Biology, 29 : 233-236.

Shrivastava, D. K. (2000). Cyanobacteria from paddy fields of Durg district of Chhattisgarh state. Phykos., 39(1) : 125-128.

Singh, R. N. (1961). Role of blue-green algae in nitrogen economy of Indian agriculture.

Srivastava, N.; Suseela, M. R.; Kiran, T. and Rubina, L. (2018). Fresh water Algal diversity of Central India. International Journal of Research and Development in Pharmacy \& Life Sciences, $7: 3039-3049$.

Tilman, D.; Socolow, R.; Foley, J. A.; Hill, J.; Larson, E.; Lynd, L. and Williams, R. (2009). Beneficial bio-fuels the food, energy, and environment trilemma. Science, 325(5938) : 270-271.

Tiwari, A. and Chauhan, S. V. S. (2006). Seasonal phytoplanktonic biodiversity of Kitham lake, Agra. Journal of Environmental Biology, 27 : $35-38$. 